\title{
Chert procurement in Corsica during the Neolithic: Inferring social territories in the Tyrrhenian islands
}

\author{
Céline Leandri ${ }^{1}$, Paul Fernandes ${ }^{2}$ \\ 1. Ministère de la Culture, DRAC de Corse; TRACES, UMR 5608. Ajaccio, France. \\ Email: celine.leandri@culture.gouv.fr \\ 2. SARL Paleotime; PACEA, UMR 5199. Villard-de-Lans, France. Email: paul.fernandes@paleotime.fr
}

\begin{abstract}
:
From the Neolithic, foreign siliceous materials were imported into Corsica as the island lacks local chert and obsidian. Such a context constitutes a real opportunity to investigate the relationship of the island with surrounding areas, in perspective with cultural evolutions. For 20 years, chert sourcing studies were carried out. We took into account 26 sites, dating from the Ancient Neolithic to the Final Neolithic. The work is based on non-destructive petro-archaeological observations of the artefacts. and on the survey and characterization of Sardinian sources (320 samples collected and 60 different lithotypes characterized).

The study aims to better understand the place of chert among the lithic assemblages throughout time and identify the provenance of most of the chert material introduced into Corsica. It reveals procurement evolution in terms of preferred facies and of stages of introduction, depending on the chronology and geographical situation of the sites. The results confirm connections with Sardinia, among which Perfugas basin constitutes a major source of raw material for Corsica. It also shows relations with the Italian Peninsula for some Middle Neolithic sites in Northern Corsica. Comparisons with data from Sardinia show the affinities and differences between the two islands and open further avenues for research.
\end{abstract}

Keywords: chert; Corsica; provenance; Neolithic; Sardinia

\section{Introduction and background}

Lithic raw material provenance studies can evidence connections between different geographic areas. The relationships between those areas, considered as a territory, can be interpreted in terms of economic, cultural and or social processes. Data on lithic procurement sources highlight one particular aspect of territory which is variable as regard to its extension and temporality depending on exploited resources and social networks.

We developed such an approach on Corsican chert procurement in order to contribute to the understanding of Neolithic diffusion and evolution in the Western Mediterranean. Corsica, as a Tyrrhenian island, appears a key area. Its geological environment lacks suitable raw

Journal of Lithic Studies (2020) vol. 7, nr. 2, p. 1-24 DOI: https://doi.org/10.2218/jls.5406

Published by the School of History, Classics and Archaeology, University of Edinburgh

ISSN: 2055-0472. URL: http://journals.ed.ac.uk/lithicstudies/

Except where otherwise noted, this work is licensed under a CC BY 4.0 licence. 
material, such as chert and obsidian, for knapping (Bressy-Leandri 2016). Locally occurring filonian quartz, rhyolite and Lydian stone were all exploited during prehistory.

In Corsica, works on lithic sourcing can be traced back to the 1980s and were first focused on obsidian (de Lanfranchi 1980; Tykot 1996). However major advances occurred at the beginning of the 2000s, with an increase in the number of samples taken into account, as well as the type of raw material analysed, including: obsidian (Le Bourdonnec et al. 2005), flint (Bressy et al. 2007, 2008), rhyolite (Ameziane-Federzoni 2011) and polished rocks (Colonna et al. 2014).

The first populating of Corsica dates back to the $9^{\text {th }}$ millennium. Ten Mesolithic sites are known from around the island, mainly in coastal areas. For this period, lithic procurement targeted local pebbles. A single Mesolithic chert bladelet from Punta di Caniscione has been related to Sardinian sources (Pasquet \& Demouche 2008: 39). From the Earliest Neolithic sites $\left(6^{\text {th }}\right.$ millennium), foreign raw materials, obsidian and chert, appeared in large quantities in Corsica, constituting a significant portion of lithic assemblage beside local materials (quartz, rhyolite).

For the last 20 years, 37 Corsican archaeological assemblages dating from the Ancient Neolithic to the Final Neolithic (5800-2000 cal. BCE) have been studied and compared to the closest potential chert outcrops, which are mainly located in Sardinia. A non-destructive petro-archaeological approach has been undertaken.

Our first aim was to identify source-areas and define the limits of the territories. Secondly, we sought the evolution of procurement patterns and of the organization of territories during the Neolithic period. Lastly, we considered possible interpretations in terms of economic, social and cultural processes. We are now able to present a regional and long term synthesis of chert procurement in Corsica for the Neolithic period.

\section{Site corpus}

In Corsica, about a hundred excavated sites have provided Neolithic remains. Considering the poor extent of some of these sites, the poor documentation, especially for the oldest excavations, and the absence or scarcity of lithic remains in others, we took into account a corpus of 26 sites, ranging from the Ancient Neolithic to the Final Neolithic (Table 1) distributed across the whole island. As some sites have multiple layers, we actually studied 12 lithic assemblages for the Ancient Neolithic (5800-4900 cal. BCE), 18 for the Middle Neolithic (4900-3900 cal. BCE), six for the Recent Neolithic (3900-3000 cal. BCE), and one for the Final Neolithic (3000-2000 cal. BCE). Among our corpus, the context reliability is variable (Table 1 , see $8^{\text {th }}$ column). We excluded from the results the sites with the poorest reliability but information from these sites may feed the global reflection on raw material procurement. Although we look for the best representativeness of the data, different parameters induce heterogeneity. Sites were excavated at different periods, with different methods and recording devices. For the oldest excavations, some material may be lost. Moreover, raw material counts (Table 1) were based on different sources of information: bibliography (original reports) or current lithic remains counts. In some cases, however, it was not possible to obtain the information (cf. “data not available”). 
Table 1. Descriptive list of the analysed sites and respective distribution of lithic raw materials.

Abbreviations: map ref. - map references; SU - Stratigraphic unit; NA - data not available; materials: Q - quartz; R - rhyolite; Ot - other; Ob - obsidian; Ch - chert; TN - total

n; Layer or SU: STR - structure; SU - stratigraphic unit; site types: RS - rock shelter; OAD - open air dwelling; OAS - open air site; D - dwelling; M - megalithism; B -

burial; people: PNb - P. Nebbia; AA - A. D'Anna; TP - T. Perrin; JM - J. Magdeleine; MW - M.-C. Weiss; FLo - F. Lorenzi; SM - S. Mazet; FdL - F. de Lanfranchi; AP - A.

Pasquet; PT - P. Tramoni; FLe - F. Leandri; PNv - P. Neuville; GP - G. Peretti; KPQ - K. Peche-Quilichini; CR - C. Ranché; chrono-cultural attribution: IW - Impressed

ware; CW - cardial ware; EC - Epicardial; TE - Tyrrhenian Epicardial; MN - Middle Neolithic; RN - Recent Neolithic; LN - Late Neolithic

\begin{tabular}{|c|c|c|c|c|c|c|c|c|c|c|c|c|c|c|}
\hline \multirow{2}{*}{ 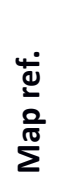 } & \multirow[b]{2}{*}{ Site (city) } & \multirow{2}{*}{ 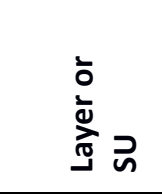 } & \multirow{2}{*}{ 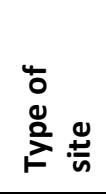 } & \multirow{2}{*}{ 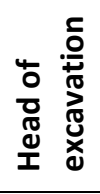 } & \multirow{2}{*}{ 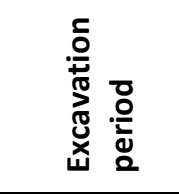 } & \multirow{2}{*}{ 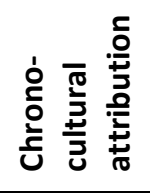 } & \multirow{2}{*}{ 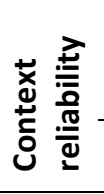 } & \multicolumn{6}{|c|}{ Lithic raw material distribution (n) } & \multirow[b]{2}{*}{ Counts source } \\
\hline & & & & & & & & $\mathbf{Q}$ & $\mathbf{R}$ & Ot & $\mathrm{Ob}$ & Ch & TN & \\
\hline & Ancient Neolithic & & & & & & & & & & & & & \\
\hline 1 & Campu Stefanu (Sollacaro) & SU 108 & RS & PNb & $2005-2011$ & IW & $* * *$ & 410 & 52 & 18 & 36 & 14 & 530 & Cesari et al. 2014 \\
\hline 2 & Renaghju (Sartène) & phase 1 & OAD & $\mathrm{AA}$ & $1994-2000$ & CW & $* * *$ & 1276 & 390 & 0 & 653 & $\begin{array}{c}198 \\
4\end{array}$ & 4303 & Bressy et al. 2007 \\
\hline 3 & Basi (Serra-di-Ferro) & SU 1011 & OAD & TP & 2016-2019 & $\mathrm{CW}$ & $* * * *$ & 28 & 8 & 24 & 45 & 130 & 199 & Perrin 2016 \\
\hline 4 & Strette (Barbaggio) & c. XIV & RS & JM & 1978-1982 & CW & $* * * *$ & 251 & 32 & 33 & 90 & 13 & 419 & Bressy-Leandri 2014 \\
\hline 5 & A Petra (L'île-Rousse) & c. la to IIf & OAD & MW & $1983-2007$ & CW; EC & $* *$ & 10 & 1827 & 28 & 785 & 23 & 2673 & Sicurani 2008 \\
\hline 6 & Grotte Southwell (Vivario) & & RS & $\mathrm{TP}$ & 2015 & $\mathrm{CW}$ & $*$ & 83 & 257 & 3 & 22 & 5 & 370 & Perrin 2015 \\
\hline 7 & A Lumaca (Centuri) & & OAS & FLo & $1994-2000$ & $\mathrm{CW}$ & $*$ & NA & NA & NA & NA & 14 & & \\
\hline 8 & Abri des Castelli (Corte) & c. 3 & RS & SM & $2008-2012$ & CW & $* * *$ & 94 & 4223 & 23 & 41 & 6 & 4387 & Martinet 2019 \\
\hline 9 & $\begin{array}{l}\text { Araguina-Sennola } \\
\text { (Bonifacio) }\end{array}$ & c. XVII & RS, B & $\mathrm{FdL}$ & $1966-1976$ & TE & $* * *$ & NA & NA & NA & NA & NA & NA & \\
\hline 10 & A Guaita (Morsiglia) & c. 3 & OAS & FLo & 2004-2013 & TE & $*$ & NA & & & & 8 & - & \\
\hline 11 & $\begin{array}{l}\text { Torre d'Aquila } \\
\text { (Pietracorbara) }\end{array}$ & c. 6 & $\mathrm{RS}, \mathrm{B}$ & $\mathrm{JM}$ & 1986-1992 & TE & $*$ & 88 & 20 & 30 & 69 & 15 & 222 & $\begin{array}{l}\text { Bressy-Leandri et al. } \\
2019\end{array}$ \\
\hline \multirow[t]{2}{*}{4} & Strette (Barbaggio) & C. XIII & RS & $J M$ & 1978-1982 & EC & $* * * *$ & 468 & 20 & 22 & 56 & 7 & 573 & Bressy-Leandri 2014 \\
\hline & Middle Neolithic & & & & & & & & & & & & & \\
\hline 1 & Campu Stefanu (Sollacaro) & SU 105 & RS, D & $\mathrm{PNb}$ & $2005-2011$ & MN 1 & $*$ & 66 & 8 & 11 & 16 & 13 & 114 & Cesari et al. 2014 \\
\hline 12 & $\begin{array}{l}\text { Pointe de Murtoli } \\
\text { (Sartène) }\end{array}$ & & OAD & $\mathrm{AP}$ & $1982-1986$ & MN 1 & & 278 & 0 & 226 & 83 & 28 & 399 & Bressy-Leandri 2019 \\
\hline 13 & Vasculacciu (Figari) & & $\begin{array}{l}\text { OAS, } \\
\text { M }\end{array}$ & PT & 2001-2003 & $\begin{array}{l}\text { MN } 1 \\
\text { and } 2\end{array}$ & $* *$ & 183 & 89 & 47 & $\begin{array}{c}230 \\
3\end{array}$ & 238 & 2860 & Bressy et al. 2008 \\
\hline 11 & $\begin{array}{l}\text { Torre d'Aquila } \\
\text { (Pietracorbara) }\end{array}$ & c. 5 & RS & $\mathrm{JM}$ & $1986-1987$ & $\begin{array}{l}\text { MN } 1 \\
\text { and } 2\end{array}$ & $* * *$ & 139 & 3 & 4 & 23 & 0 & 169 & Bressy-Leandri 2019 \\
\hline
\end{tabular}




\begin{tabular}{|c|c|c|c|c|c|c|c|c|c|c|c|c|c|c|}
\hline \multirow{2}{*}{$\begin{array}{l}\stackrel{0}{0} \\
\frac{0}{2} \\
\sum\end{array}$} & \multirow[b]{2}{*}{ Site (city) } & \multirow{2}{*}{ 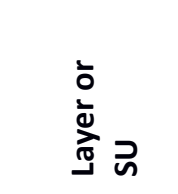 } & \multirow{2}{*}{ 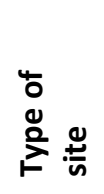 } & \multirow{2}{*}{ 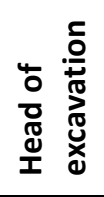 } & \multirow{2}{*}{ 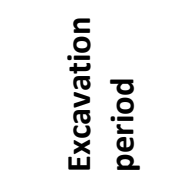 } & \multirow{2}{*}{ 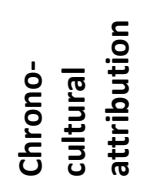 } & \multirow{2}{*}{ 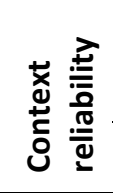 } & \multicolumn{6}{|c|}{ Lithic raw material distribution (n) } & \multirow[b]{2}{*}{ Counts source } \\
\hline & & & & & & & & $\mathbf{Q}$ & $\mathbf{R}$ & Ot & $\mathrm{Ob}$ & Ch & TN & \\
\hline 4 & $\begin{array}{l}\text { Strette I, Strette II } \\
\text { (Barbaggio) }\end{array}$ & $\begin{array}{l}\text { c. XII et c. } \\
\text { XIX }\end{array}$ & RS & $\mathrm{JM}$ & $1978-1982$ & $\begin{array}{l}\text { MN } 1 \\
\text { and } 2\end{array}$ & & 1436 & 22 & 66 & 57 & 7 & 1588 & Bressy-Leandri 2014 \\
\hline 9 & $\begin{array}{l}\text { Araguina-Sennola } \\
\text { (Bonifacio) }\end{array}$ & c. $X V$ & RS & $\mathrm{FdL}$ & 1966-1976 & $\begin{array}{l}\text { MN } 1 \\
\text { and } 2\end{array}$ & $* * *$ & NA & NA & NA & NA & NA & NA & \\
\hline 14 & I Stantari (Sartène) & phase 1 & $\begin{array}{c}\text { OAS, } \\
M\end{array}$ & AA & 2001-2012 & MN 2 & $*$ & $N D$ & $N D$ & $N D$ & 95 & 14 & - & \\
\hline 2 & Renaghju (Sartène) & phase 3 & $\mathrm{M}$ & AA & $1994-2000$ & MN 2 & & NA & NA & NA & NA & NA & NA & \\
\hline 15 & $\begin{array}{l}\text { Monte Revincu (Sto-Petro- } \\
\text { di-Tenda) }\end{array}$ & & $D, M$ & FLe & $1995-2007$ & MN 2 & $* * * *$ & 7458 & 39 & 4 & 148 & 54 & 7703 & Bressy-Leandri 2016 \\
\hline 16 & A Fuata (Lumio) & SUIV b & OAD & $\mathrm{PNV}$ & 1997-2007 & MN 2 & $* * *$ & ND & ND & ND & ND & 2 & 1214 & $\begin{array}{l}\text { Le Bourdonnec et al. } \\
2010\end{array}$ \\
\hline 8 & Abri des Castelli (Corte) & c. 2 & RS & SM & 2008-2012 & MN 2 & $* * *$ & 461 & 3005 & 38 & 142 & 1 & 3647 & Martinet 2017 \\
\hline 17 & $\begin{array}{l}\text { Scaffa Piana (Poggio- } \\
\text { d'Oletta) }\end{array}$ & $\begin{array}{l}\text { c. XX, XXI, } \\
\text { XXII }\end{array}$ & RS & $J M$ & $1977-1978$ & MN 2 & $* * *$ & 263 & 17 & 40 & 50 & 4 & 374 & Bressy-Leandri 2019 \\
\hline 10 & A Guaita (Morsiglia) & c. $2 b$ & OAD & FLo & 2004-2013 & MN 2 & $*$ & NA & NA & NA & NA & 13 & & \\
\hline 18 & Abri de la Figue (Sartène) & & RS & $A P$ & 1987-1989 & MN 2 & & 1133 & 19 & & 99 & 19 & 1270 & Bressy-Leandri 2019 \\
\hline 19 & Bufua III (Figari) & & OAS & $A P$ & 1990 & MN 2 & & 43 & 1 & 0 & 74 & 30 & 148 & Bressy-Leandri 2019 \\
\hline 20 & San Vincente (Sartène) & & B & GP & 1969 & MN 2 & & 349 & 38 & 0 & 9 & 3 & 399 & Bressy-Leandri 2019 \\
\hline 21 & Abri du sanglier (Sartène) & & RS & $A P$ & $1982-1986$ & $\mathrm{MN}$ & & 210 & 0 & 234 & 45 & 8 & 497 & Bressy-Leandri 2019 \\
\hline \multirow[t]{2}{*}{22} & $\begin{array}{l}\text { Contra Maio (Petreto- } \\
\text { Bichisano) }\end{array}$ & Various SU & $\begin{array}{l}\text { OAS, } \\
M\end{array}$ & KPQ & 2018-2019 & $\mathrm{MN}$ & $* *$ & 971 & 0 & 1 & 47 & 9 & 1028 & Bressy-Leandri 2019 \\
\hline & Recent Neolithic & & & & & & & & & & & & & \\
\hline 23 & Monti Barbatu (Olmeto) & $\begin{array}{l}\text { Various } \\
\text { STR./SU }\end{array}$ & OAD & KPQ & $2017-2019$ & $\mathrm{RN}$ & $* * *$ & 3609 & 23 & - & 463 & 24 & 4119 & Bressy-Leandri 2019 \\
\hline 3 & Basi (Serra-di-Ferro) & Various SU & OAD & $\mathrm{TP}$ & 2016-2019 & $\mathrm{RN}$ & $* * * *$ & 172 & NA & NA & 525 & 12 & & Perrin 2016 \\
\hline 24 & Cardiccia (Sartène) & & $M$ & $\mathrm{PNb}$ & 1981 & $\mathrm{RN}$ & $*$ & 40 & 45 & 4 & 747 & 31 & 867 & Bressy-Leandri 2019 \\
\hline 25 & Montlaur (Bonifacio) & Various SU & OAS & $\mathrm{CR}$ & 2017 & $\mathrm{RN}$ & $* * *$ & NA & NA & NA & NA & 330 & & Ranché in prep. \\
\hline 26 & Musuleu (Porto-Vecchio) & S4 & OAS & PT & 1998 & $\mathrm{RN}$ & $* * *$ & 62 & - & - & 68 & 13 & 143 & Bressy-Leandri 2019 \\
\hline \multirow[t]{2}{*}{10} & A Guaita (Morsiglia) & c. $2 a$ & $O A D$ & FLo & $2004-2013$ & RN & $*$ & NA & NA & NA & NA & 7 & - & \\
\hline & Late Neolithic & & & & & & & & & & & & & \\
\hline 3 & Basi (Serra-di-Ferro) & Various SU & OAD & TP & 2016-209 & LN & $* *$ & NA & NA & NA & NA & NA & NA & Perrin 2016 \\
\hline
\end{tabular}




\section{Methodology}

We undertook a non-destructive petro-archaeological approach on both archaeological and geological samples. Chert sourcing was based on the description of sedimentary microfacies, as defined from optical observations under water film, with a stereomicroscope at magnifications between 8× and 60× (Bressy 2003: 23-35; Fernandes 2012: 141). We took into account 36 criteria related to mineralogy, detrital, clastic and organic components and bioclasts, recording qualitative and semi-quantitative data (size and abundances). We also considered porosity, cortex and the infra-cortical zone as a clue of alteration processes in secondary deposits, following the "chaîne évolutive concept" elaborated by Fernandes et al. (2007). Ten geological samples were selected for thin-section and petrographic analysis in order to obtain information on mineralogy and silicification processes.

Source assignments were proposed from comparisons of artefacts with geological samples from Sardinia (Figure 1) and Italian Peninsula chert source areas. Some limitations, however, may come from white patina or/and thermal alteration that affects a variable fraction of cherts in a given assemblage. In such cases, depending on the importance of these effects, some cherts were classified as 'undeterminable'.

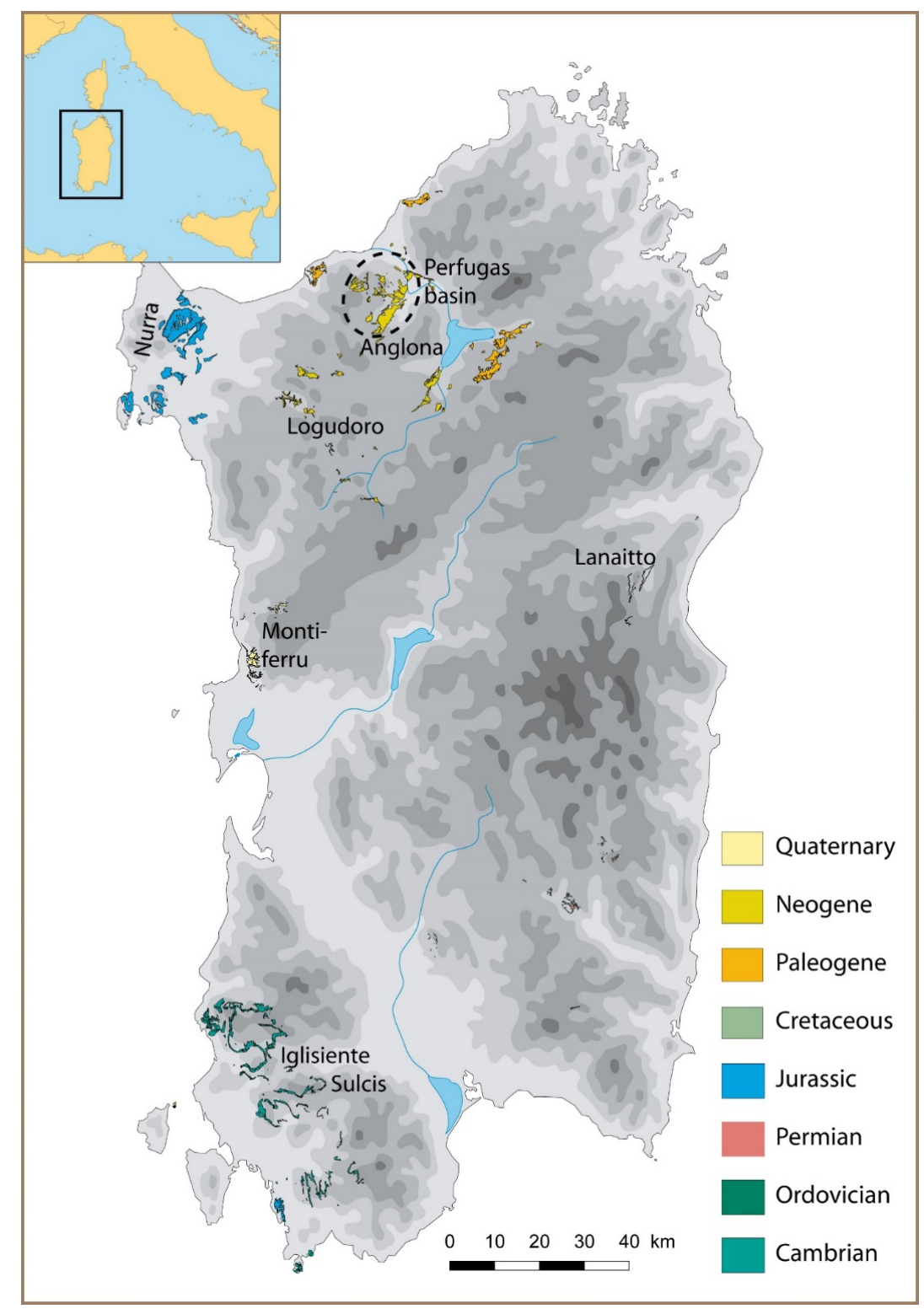

Figure 1. Sardinia chert bearing formations.

Journal of Lithic Studies (2020) vol. 7, nr. 2, p. 1-24 doi: https://doi.org/10.2218/jls.5406 
We also recorded basic technological classification (tool, flake, blade or bladelet, nucleus, technical artefact, chip), the weight of each artefact, the size range (below $1 \mathrm{~cm}$, between $1 \mathrm{~cm}$ and $2 \mathrm{~cm}$, above $2 \mathrm{~cm}$ ), and the occurrence and type of cortex.

From a methodological point of view, chips were also examined but mostly classified, considering the limited surface of observation as "undeterminable".

In addition to the study of the chert artefacts, we also tried to consider the importance of chert in the assemblages compared to locally available raw materials (quartz, rhyolite, obsidian and other rocks), notwithstanding the concerns mentioned above (data availability, heterogeneity of data).

\section{Raw material availability}

The efficiency of chert sourcing is highly dependent on the knowledge of siliceous resources in a given area. For our purpose, Sardinia represents a key area. Sardinia's chert sources were poorly documented before our work (Bressy-Leandri et al. 2019). In Sardinia, geological maps and bibliographies indicate chert bearing formations, although without considering knappable qualities, in Cambrian (Sulcis-Iglesiente area), Permian (South Eastern Sardinia), Jurassic (Nurra and Sulcis), Cretaceous (Lanaitto area) and Neogene-Paleogene (Northern Sardinia) units. Cherts from those formations can also be reworked in Quaternary formations (Montiferru massif). Our surveys specifically focused on the Perfugas Miocene basin, known for its abundance and the quality of chert (Falchi et al. 2012; Melosu 2013: 4952). This area was intensively surveyed for the last five years. Within the Rio Minore chert bearing formation, which represents about $40 \mathrm{~km}^{2}$, we sampled about eight blocks $/ \mathrm{km}^{2}$. Among the 320 samples collected (mainly in primary positions) in 114 locations, nearly 60 different lithotypes were characterized and illustrated. A lithotheca regrouping those samples has been constituted in the premises of the Service régional de l'Archéologie in Ajaccio. We proposed a classification (coded SP1 to SP8) which is supported by an atlas-catalogue illustrated by both macroscopic and mesoscopic (up to 60 magnification) view of the facies (Bressy-Leandri et al. 2019). Among those facies, some are very specific to the area and show high knapping properties (Figure 2). They occur frequently in lithic assemblages. A special mention must be made regarding a facies called SC. It is a calcedonious (translucent) facies which is highly variable in colour (brown, white, grey). Its occurs in the Perfugas area but is not specific to the area. Further survey must be conducted to determine the extent of SC availability, which appears to be mainly in located in a secondary position.

For the Italian Peninsula raw material, we fostered collaborations with Italian specialists (Ferrara University) and CEPAM lithotheca. 

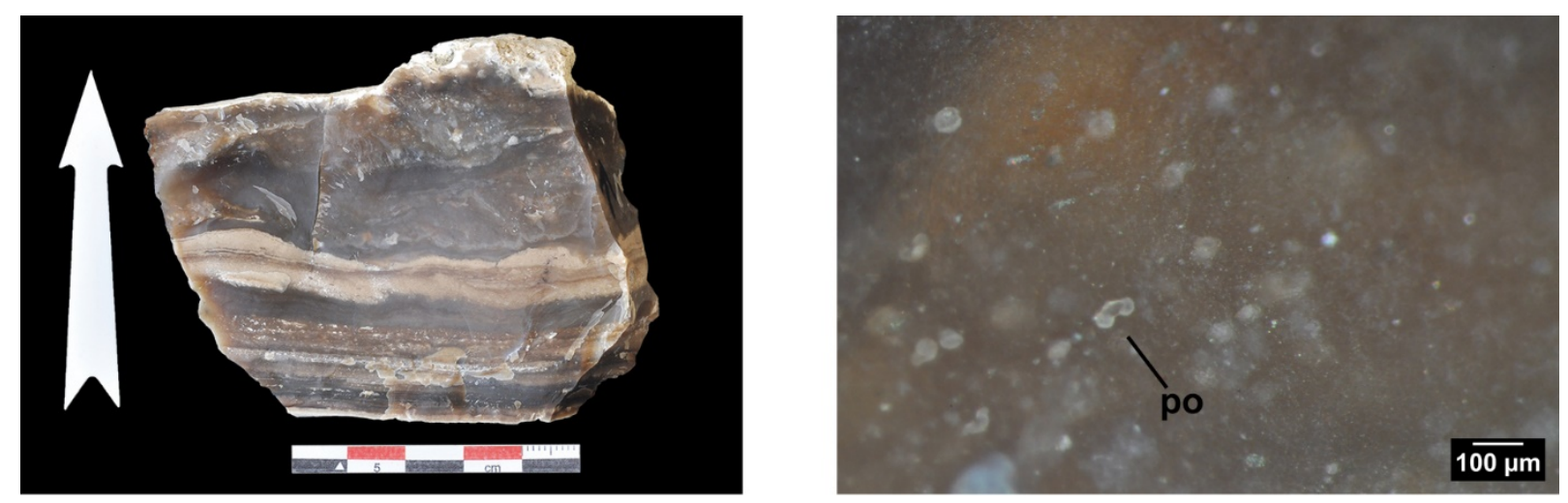

Monte Finuiu, SP1 : bedding chert with pollen (po) beds
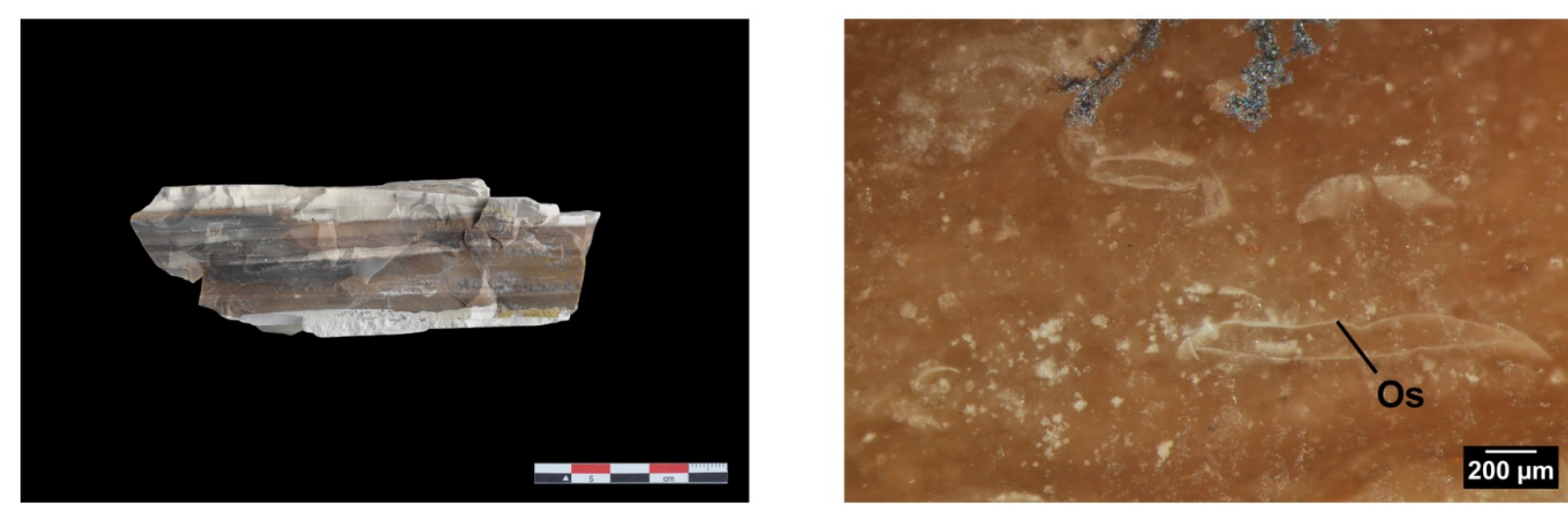

Sa Pria, SP1 : bedding chert with Ostracods (Os) beds
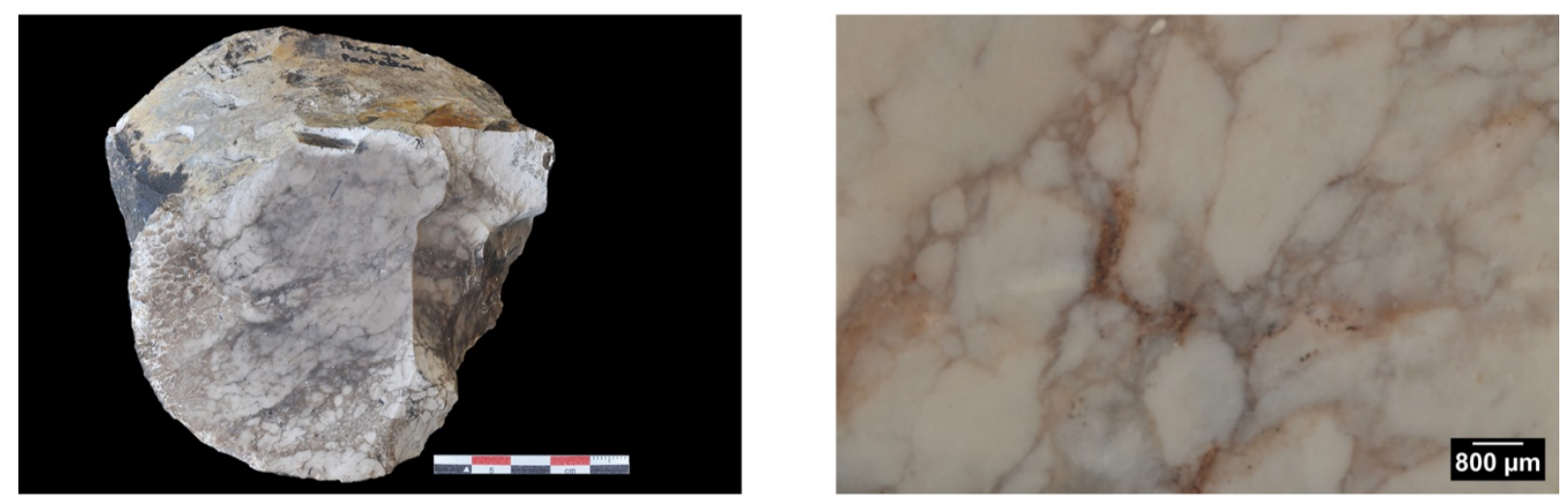

Pantalinu, SP2a : evaporitic chert with chicken wire structure
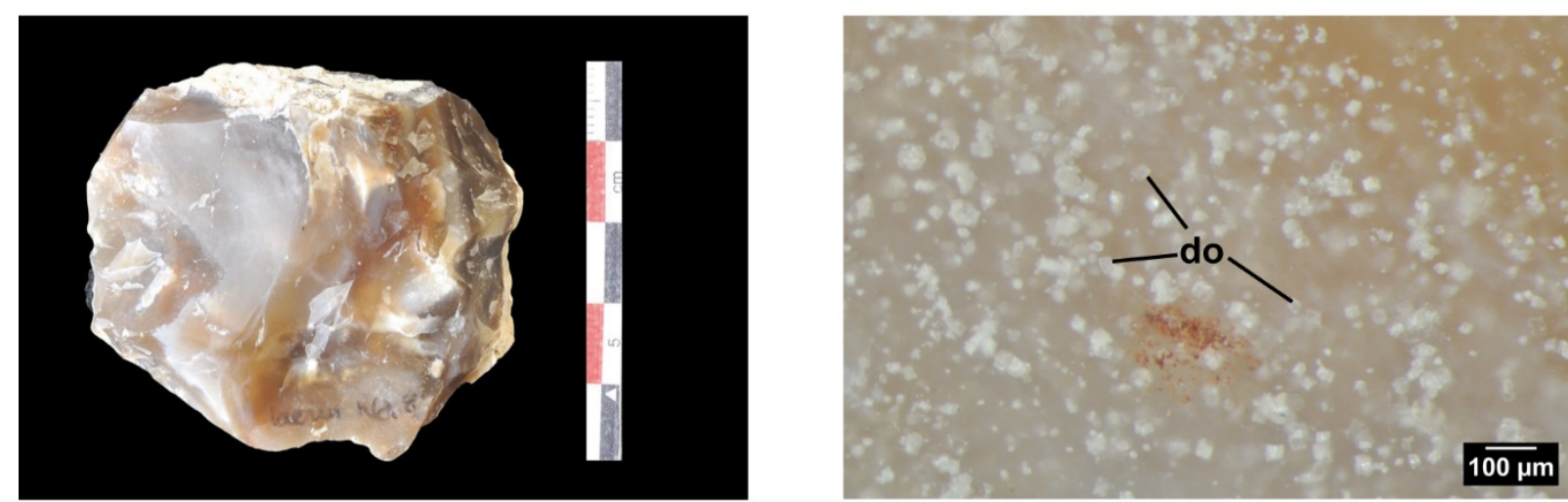

Laerru, SP5 : translucent chert with rhomboedric crystals (dolomite, do)

Figure 2. Selection of main facies of Perfugas basin (macroscopic and mesoscopic photography).

Journal of Lithic Studies (2020) vol. 7, nr. 2, p. 1-24 doi: https://doi.org/10.2218/jls.5406 


\section{Results}

Currently, 3141 chert artefacts have been studied. Among them, 778 could not be identified because of patina or heat alteration. The percentage of undetermined chert is highly variable, depending on the site.

The results consider both the part played by chert in knapped industries (Table 1, Figures 3 to 5 , including sites for which chert provenance is not studied yet), and the provenance analysis for each chronological period.

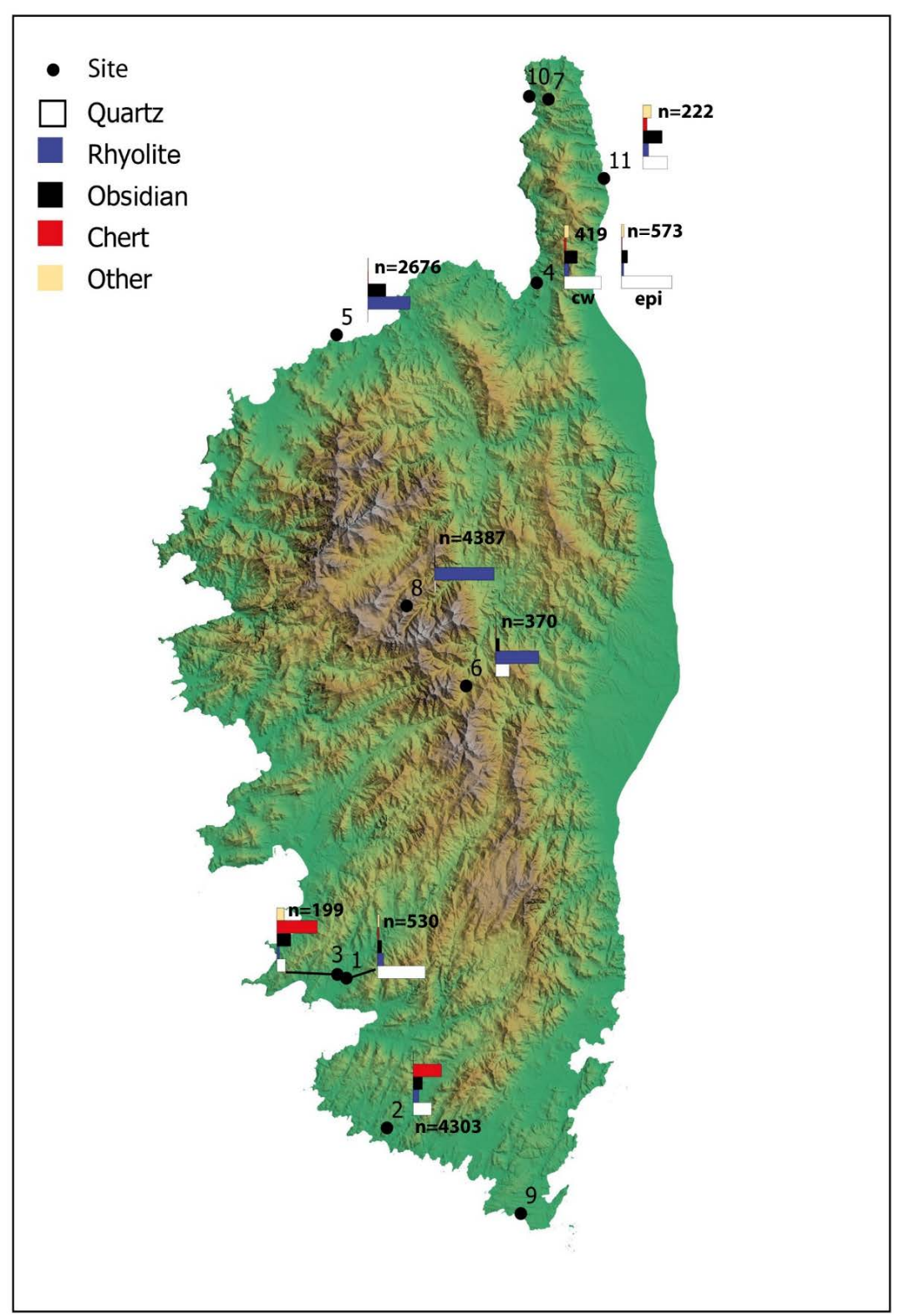

Figure 3. Location of Ancient Neolithic sites, including representation of raw material distribution when data available. Site number corresponds to first column in table 1; n: total number of lithic artefacts represented in the diagram; cw: Cardial ware; epi: Epicardial. Credits: Maxime Seguin, DRAC Corse.

Regarding the data, preliminary concerns must be raised, particularly around the proportion of quartz in an assemblage, as quartz constitutes a local material often available in the immediate vicinity of the sites (less than one $\mathrm{km}$ ). Depending on the specific excavation, it may not have been taken into account the same way: discarded in some cases, over represented in others as not all quartz specimens are part of the knapped industry. Typotechnological studies of quartz are also often not available. Keeping these remarks in mind, 
the presentation of raw material patterns per site and period (Figures 3 to 5), allow some observations to be made, including some sites showing particular patterns of raw material use. For example, in certain mountain sites, rhyolite represents the major part of the knapped industry, including sites such as Grotte Southwell, Abri des Castelli (Figure 3) and the Plateau d'Alzu (Figure 5). These sites are localized the vicinity of rhyolite outcrops. This can either show a preferential use of local raw material when it is available and of suitable quality, or an exploitation turned towards the diffusion of rhyolite, or both.

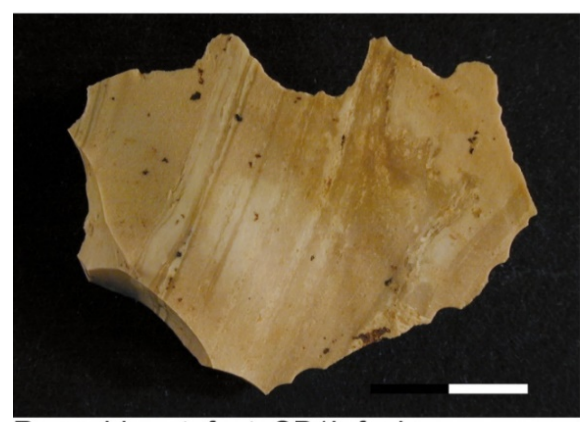

Renaghju artefact, SP1b facies (ref. : U32, 9924)

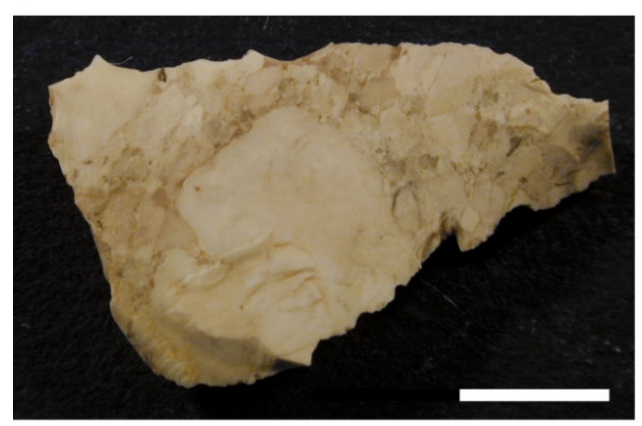

Renaghju artefact, SP2a facies (ref. : T30, 9320)

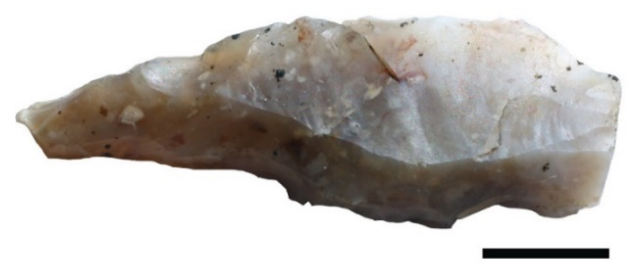

Basi artefact, SC oxides facies (ref. : US 1018)

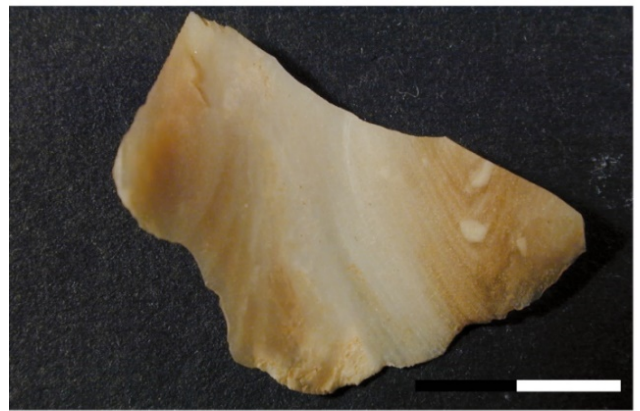

Renaghju artefact, SP5a facies (ref. : R30, 9816)

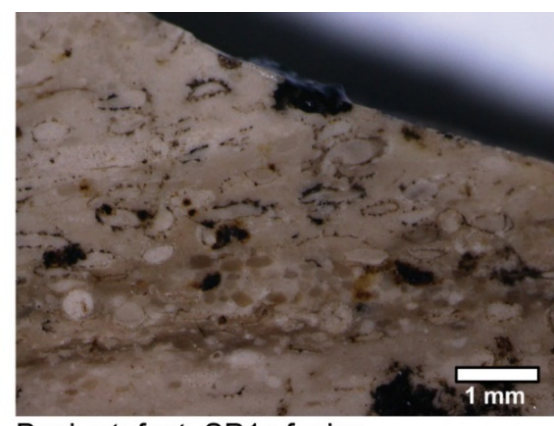

Basi artefact, SP1c facies (ref. : US 1011, $n^{\circ} 54$ )

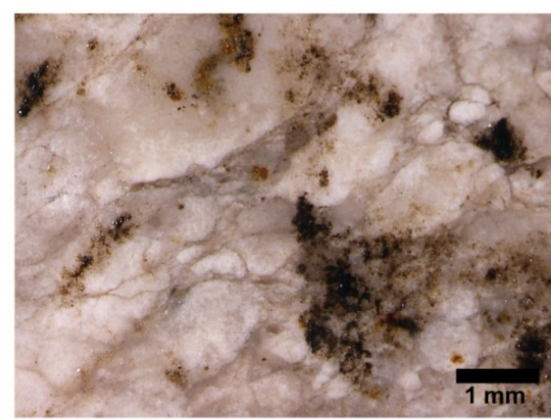

Basi artefact, SP2a facies (ref. : US 1011, n²5)
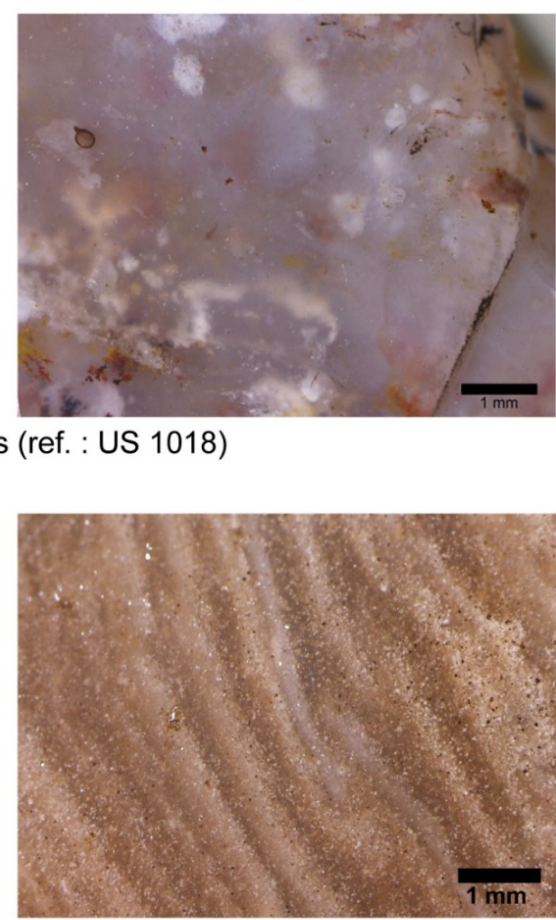

Basi artefact, SP5a facies (ref. : US 1405, $\mathrm{n}^{\circ} 101$ )

Figure 4. Examples of facies of Basi and Renaghju artefacts (macroscopic and mesoscopic photography).

Journal of Lithic Studies (2020) vol. 7, nr. 2, p. 1-24 doi: https://doi.org/10.2218/jls.5406 


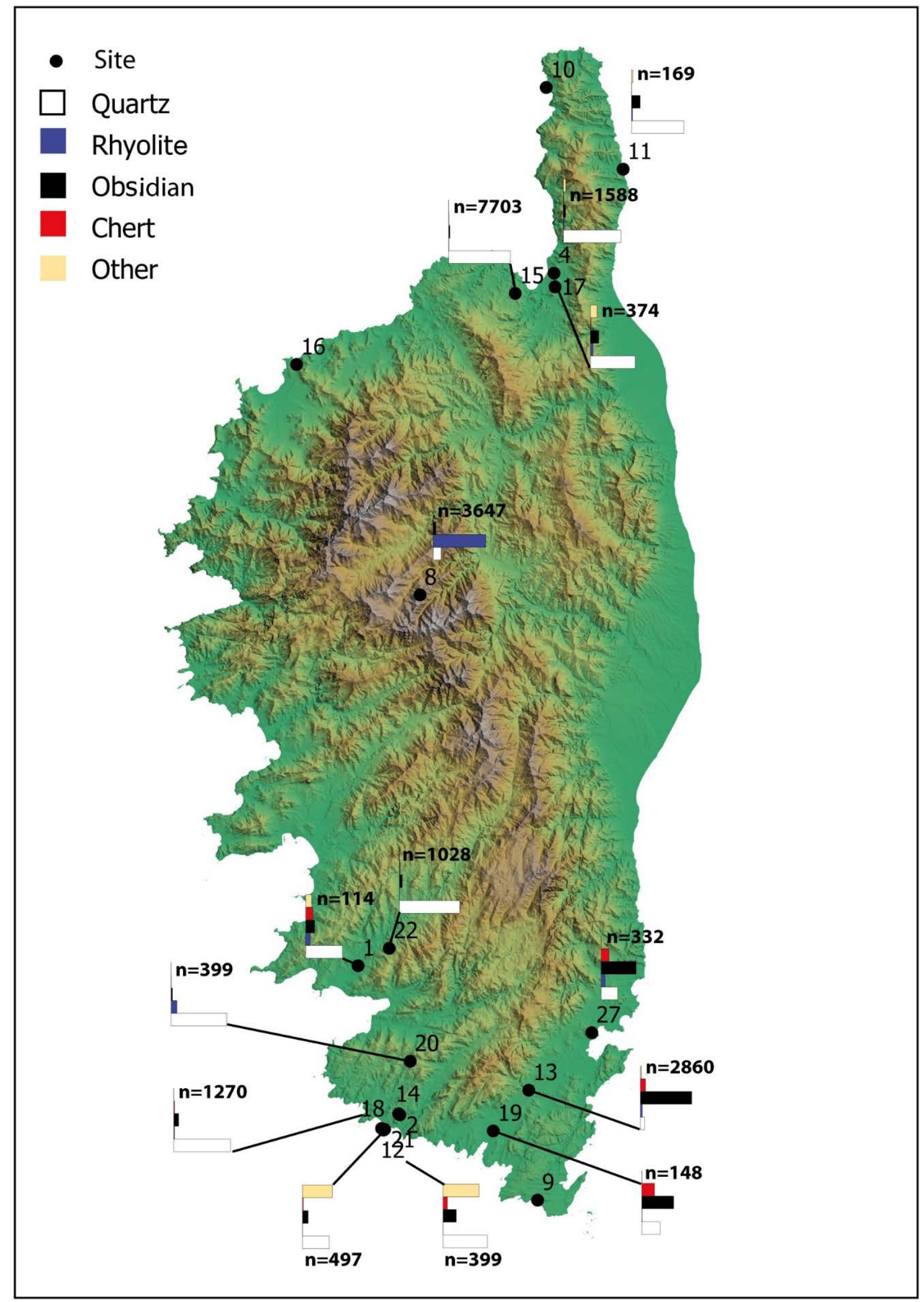

Figure 5. Location of Middle Neolithic sites and representation of raw material distribution when data available. Site number corresponds to first column in Table 1, and, in addition: 27: Foce di Termini; n: total number of lithic artefacts represented in the diagram. Credits: Maxime Seguin, DRAC Corse. 


\subsection{Ancient Neolithic}

During this period, regarding lithic raw material patterns (Figure 3), various cases can be observed: in the southern sites of Basi and Renaghju the proportions of chert are higher to that of obsidian (around three times higher). The situation is totally different for the neighbouring site of Campu Stefanu, where the number of imported artefacts is limited.

In Northern Corsica, including mountain sites like Grotte Southwell and Abri des Castelli, the amount of imported material is significantly lower (below 20 artefacts for chert and 100 for obsidian) than in the south of the island, excepting A Petra. Those sites show an opposite trend compared to Basi and Renaghju where obsidian use is always higher than that of chert.

The site of A Petra displays specific characteristics (Figure 3) as it exhibits a high proportion of rhyolite, which is not observed elsewhere except in mountain sites close to the sources, and also a very high number of obsidian (about 800 pieces) compared to other northern sites (less than a hundred), which is equivalent to the southern sites. This high use of obsidian may be related to the specific placement of this site, as it is located on a rocky peninsula along the western coast of the island which could play a part in the redistribution of obsidian toward Northern areas.

The sites or layers attributed to the Epicardial (A Guaita, Torre d'Aquila, Strette, Araguina) do not reveal clear raw material differences when compared to the Cardial sites and layers.

Regarding chert provenance data, 12 Ancient Neolithic sites were initially considered for investigation. However, across the sites the reliability of chronological attribution is variable, and the number of artefacts unequal: nine sites have less than 25 chert artefacts. Therefore, only two sites provide with chronological reliability: Renaghju (nearly 2000 artefacts), and Basi (130), which is currently being excavated (Table 2, Figure 4).

From a general overview, the results show that Perfugas origin is attested in nine out of the 12 assemblages studied. In those cases, it constitutes the main procurement source among the identified material. It is mainly represented by bedded chert (SP1), evaporitic facies (SP2A) and rhomboedric features chert (SP5 facies) (Figure 6).

Those raw materials were introduced mainly as end-products in sites from Northern Corsica (Torre d'Aquila, Abri des Castelli, Strette c. XIV), while blanks predominate in Southern Corsica settlements. Typo-technological studies are available for two sites of our corpus, Renaghju and Basi (Bressy et al. 2007; Perrin 2016: 97-101). The results show quite similar patterns. The debitage of chert (and obsidian) was aimed at the production of blades and bladelets which are frequently transformed into geometric armatures and truncations. The first stages of the chaîne opératoire are represented in the industry (around 15\% of artefacts have cortex), but we observed a lack of nucleus present. 
Table 2. Petro-archaeological description of Basi artefacts facies.

Abbreviations: sorting: L - low; G - good; P - poor; habitus: TC - tabular chert; AB - angular blocks; U - undetermined; V - variable; PROV - provenance: PB - Perfugas

Basin; TD - to be determined; $\mathrm{M}$ - Montiferru.

\begin{tabular}{|c|c|c|c|c|c|c|c|c|c|c|c|c|}
\hline Faciès & $\begin{array}{l}\text { Colour, } \\
\text { structure, } \\
\text { opacity }\end{array}$ & Porosity & Clasts & Bioclasts & : & 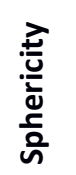 & 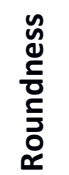 & Iron oxydes & Organic matter & Cortex & $\begin{array}{l}\frac{n}{2} \\
\frac{1}{0} \\
\frac{\pi}{1}\end{array}$ & ذั \\
\hline SP1 & $\begin{array}{l}\text { Beige to brown, } \\
\text { bedded, opaque }\end{array}$ & Fractures & $\begin{array}{l}<5 \% \text {, carbonate } \\
\text { clasts, } 100 \mu \mathrm{m}, \\
\text { pelletoids, } 250-500 \\
\mu \mathrm{m}\end{array}$ & $\begin{array}{l}\text { Variable } \\
\text { (depending on } \\
\text { the beds) }\end{array}$ & L & $\begin{array}{l}0,5- \\
0,7\end{array}$ & 0,5 & $\begin{array}{l}\text { Not } \\
\text { observed }\end{array}$ & $\begin{array}{l}\text { Debris, filament, up } \\
\text { to } 250 \mu \mathrm{m}\end{array}$ & $\begin{array}{l}\text { Tabular morphology, } \\
\text { calcareous, millimetric, } \\
\text { rugged surface, infra- } \\
\text { cortical zone frequent, } \\
\text { millimetric }\end{array}$ & TC & PB \\
\hline SP1b & $\begin{array}{l}\text { Beige to brown, } \\
\text { bedded, opaque }\end{array}$ & Fractures & $\begin{array}{l}<5 \% \text {, carbonate } \\
\text { clasts, } 100 \mu \mathrm{m}\end{array}$ & $\begin{array}{l}\text { Stromatolite } \\
\text { beds }\end{array}$ & G & $\begin{array}{l}0,5- \\
0,7\end{array}$ & 0,5 & $\begin{array}{l}\text { Not } \\
\text { observed }\end{array}$ & Debris $<100 \mu \mathrm{m}$ & $\begin{array}{l}\text { Tabular, calcareous } \\
\text { millimetric, infra-cortical } \\
\text { zone frequent, millimetric }\end{array}$ & TC & PB \\
\hline SP1C & $\begin{array}{l}\text { Beige to brown, } \\
\text { bedded, opaque }\end{array}$ & Fractures & $\begin{array}{l}<5 \% \text {, carbonate } \\
\text { clasts, } 100 \mu \mathrm{m}, \\
\text { pelletoïds, } 250-500 \\
\mu \mathrm{m}\end{array}$ & $\begin{array}{l}\text { Charophyte } \\
\text { stems (in infra- } \\
\text { cortical zone) }\end{array}$ & L & $\begin{array}{l}0,5- \\
0,7\end{array}$ & 0,5 & $\begin{array}{l}\text { Not } \\
\text { observed }\end{array}$ & $\begin{array}{l}\text { Debris, filament, up } \\
\text { to } 250 \mu \mathrm{m}\end{array}$ & Not observed & $\mathrm{TC}$ & PB \\
\hline SP2a & $\begin{array}{l}\text { White to beige } \\
\text { to brown, } \\
\text { breccia } \\
\text { appearance, } \\
\text { opaque }\end{array}$ & $\begin{array}{l}\text { Low, } \\
\text { intraparticle }\end{array}$ & $\begin{array}{l}>30 \% \text {, nodular } \\
\text { clasts, frequent, } 400 \\
\mu \mathrm{m} \text { to } \mathrm{mm}\end{array}$ & Not observed & $P$ & 0,7 & 0,1 & $\begin{array}{l}\text { Iron } \\
\text { impreg. }\end{array}$ & Not observed & $\begin{array}{l}\text { Fractured surface, with } \\
\text { high porosity, iron } \\
\text { impregnation (yellowish } \\
\text { colour) }\end{array}$ & $A B$ & PB \\
\hline SP4 & $\begin{array}{l}\text { Beige, } \\
\text { homogeneous, } \\
\text { opaque }\end{array}$ & $\begin{array}{l}\text { Former } \\
\text { regular voids } \\
\text { filled with } \\
\text { translucent } \\
\text { silica }\end{array}$ & $\begin{array}{l}\text { Scarce carbonate } \\
\text { clasts, }<5 \%,<200 \\
\mu \mathrm{m}, \text { possible } \\
\text { pelletoids, } 500 \mu \mathrm{m}\end{array}$ & Not observed & G & 0,9 & 0,5 & $\begin{array}{l}\text { Dots or } \\
\text { diffuse } \\
\text { impreg., } 50- \\
500 \mu \mathrm{m}\end{array}$ & Debris <100 $\mu \mathrm{m}$ & Calcareous, washed & TC & PB \\
\hline $\begin{array}{l}\text { SP5a, } \\
\text { SP5b }\end{array}$ & $\begin{array}{l}\text { Light grey to } \\
\text { brown, } \\
\text { laminated (a) or } \\
\text { heterog. (b), } \\
\text { semitranslucent }\end{array}$ & $\begin{array}{l}\text { Intraparticles, } \\
\text { fractures, } \\
\text { boxworks }\end{array}$ & $\begin{array}{l}<50 \mu \mathrm{m}, \\
\text { Rhomboedra } \\
\text { (probable dolomite), } \\
\text { pelloids ( } 500 \mu \mathrm{m} \text { to } \\
\text { millimetric) }\end{array}$ & Not observed & $P$ & $\begin{array}{l}0,7- \\
0,9\end{array}$ & 0,1 & $\begin{array}{l}\text { Not } \\
\text { observed }\end{array}$ & $\begin{array}{l}\text { Scarce debris }<100 \\
\mu \mathrm{m}\end{array}$ & Not observed & $U$ & PB \\
\hline
\end{tabular}

Journal of Lithic Studies (2020) vol. 7, nr. 2, p. 1-24

doi: https://doi.org/10.2218/jls.5406 


\begin{tabular}{|c|c|c|c|c|c|c|c|c|c|c|c|c|}
\hline SP6a & $\begin{array}{l}\text { Brown, } \\
\text { homogeneous, } \\
\text { opaque }\end{array}$ & Boxworks & $\begin{array}{l}20-25 \% \text {, abundant } \\
\text { carbonate clasts and } \\
\text { quartz, } 40-200 \mu \mathrm{m}\end{array}$ & Not observed & L & $\begin{array}{l}0,3- \\
0,7\end{array}$ & $\begin{array}{l}0,1- \\
0,3\end{array}$ & $\begin{array}{l}\text { Not } \\
\text { observed }\end{array}$ & Not observed & Not observed & $U$ & TD \\
\hline SP6b & $\begin{array}{l}\text { Black grey, } \\
\text { opaque (heated) }\end{array}$ & - & $\begin{array}{l}30 \% \text {, abundant } \\
\text { polygenic clasts, } 100 \\
\mu \mathrm{m} \text { to millimétric }\end{array}$ & Not observed & $\mathrm{L}$ & $\begin{array}{l}0,9- \\
0,5\end{array}$ & $\begin{array}{l}0,5- \\
0,9\end{array}$ & $\begin{array}{l}\text { Not } \\
\text { observed }\end{array}$ & Not observed & Not observed & & TD \\
\hline SP7 & $\begin{array}{l}\text { Grey to beige, } \\
\text { opaque (heated) }\end{array}$ & $\begin{array}{l}\text { Recrystallized } \\
\text { fractures }\end{array}$ & $\begin{array}{l}10 \%, \text { carbonate } \\
\text { clasts (and others?), } \\
200-500 \mu \mathrm{m}\end{array}$ & $\begin{array}{l}\text { Abundant } \\
\text { Ostracods, } \\
\text { entire } \\
\text { (recrystallized), } \\
300-500 \mu \mathrm{m} \text { or } \\
\text { isolated valve, } \\
>500 \mu \mathrm{m}\end{array}$ & G & $\begin{array}{l}0,9- \\
0,7\end{array}$ & $\begin{array}{l}0,5- \\
0,7\end{array}$ & $\begin{array}{l}\text { Not } \\
\text { observed }\end{array}$ & Not observed & Not observed & $U$ & PB \\
\hline SC & $\begin{array}{l}\text { White, grey or } \\
\text { brown, spotted, } \\
\text { translucent to } \\
\text { semitranslucent }\end{array}$ & High, vugs & $<1 \%$ & Non observés & - & - & - & $\begin{array}{l}\text { Not } \\
\text { observed }\end{array}$ & Variable & Variable & V & $\begin{array}{l}\mathrm{PB} \\
/ \mathrm{M}\end{array}$ \\
\hline $\begin{array}{l}\text { SC } \\
\text { oxydes }\end{array}$ & $\begin{array}{l}\text { Translucent, } \\
\text { homogeneous } \\
\text { with iron oxydes } \\
\text { spots (orange to } \\
\text { brown) }\end{array}$ & & $<1 \%$ & Not observed & - & - & - & $\begin{array}{l}\text { Iron oxydes } \\
\text { dendrites, } \\
300-500 \mu \mathrm{m}\end{array}$ & Not observed & Not observed & $U$ & TD \\
\hline
\end{tabular}



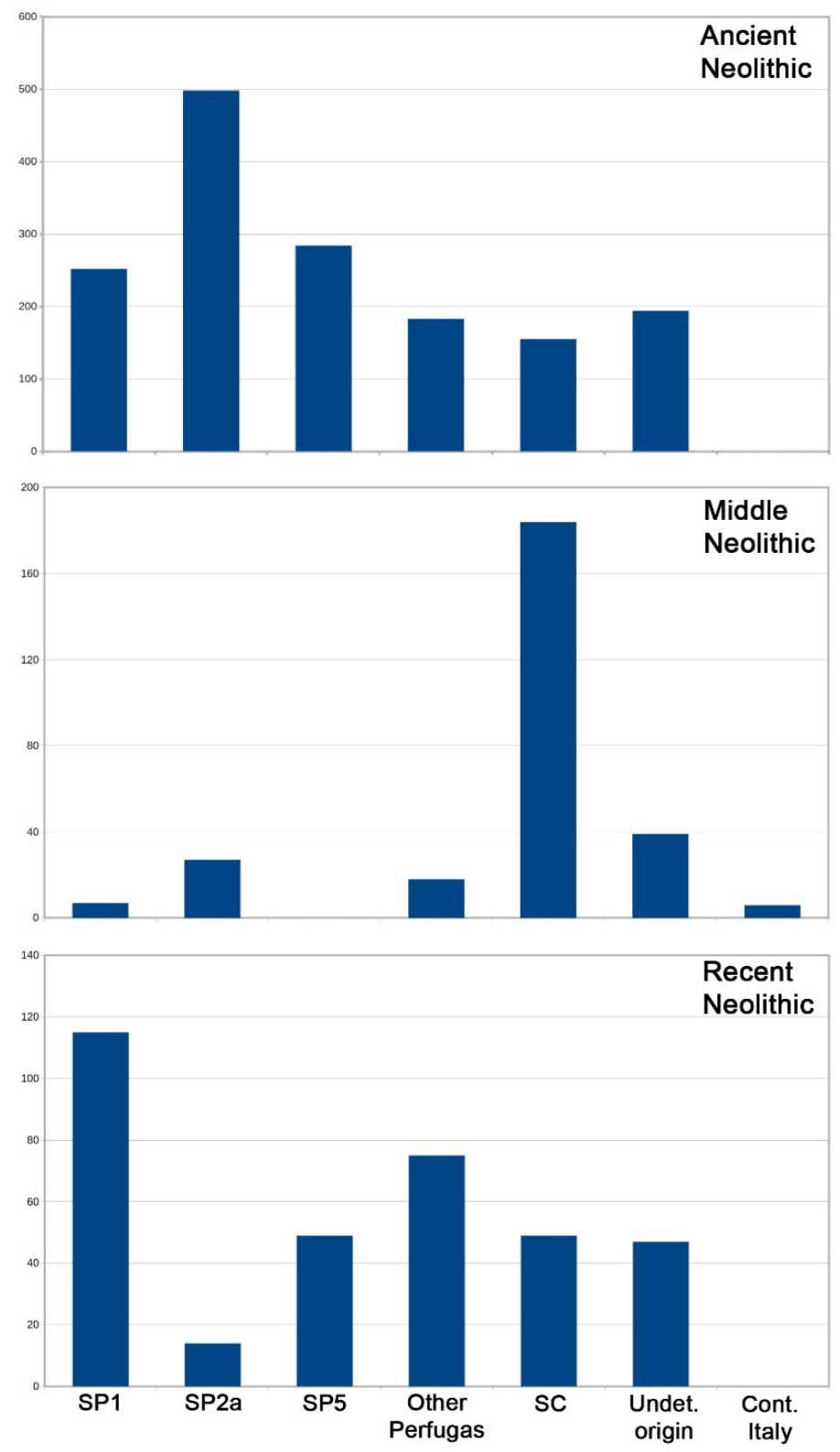

Figure 6. Cumulate diagram of number of artefacts for main identified facies of the studied sites per period. Undet. origin: undetermined origin; Cont. Italy: Continental Italy.

\subsection{Middle Neolithic}

The Middle Neolithic provides the largest corpus of studied sites. During this period, there is a major decrease in the importing of chert in favour of obsidian (Table 1). The quantities of chert artefacts vary considerably and are very poor in some sites (less than ten at seven of the sites). Only one site, Vasculacciu, exceeds 200 artefacts, which is balanced by the very high number of obsidian (2860 artefacts). But aside from that, and on the basis of the knowledge acquired so far, it is not possible to identify trends which might differentiate Northern from Southern sites regarding chert proportions. If we consider other imported material, except Vasculacciu as mentioned above, obsidian quantities are moderate (between 10 and 150 artefacts), in both Northern and Southern Corsica. Moreover, no distinction can be made between phase I and II of the Middle Neolithic.

Compared to the Ancient Neolithic, there was great change in chert facies, with the calcedonious cherts (SC type) now dominating (Figure 7). Perfugas facies are poorly 
represented (seven sites had at least one artefact). The provenance of Middle Neolithic cherts (SC) is not absolutely ascertained. Even if we cannot exclude a Perfugas origin for SC, it appears more likely to have come from secondary sources in different areas, as we observed alluvial stigmata on the scarce cortical artefacts.

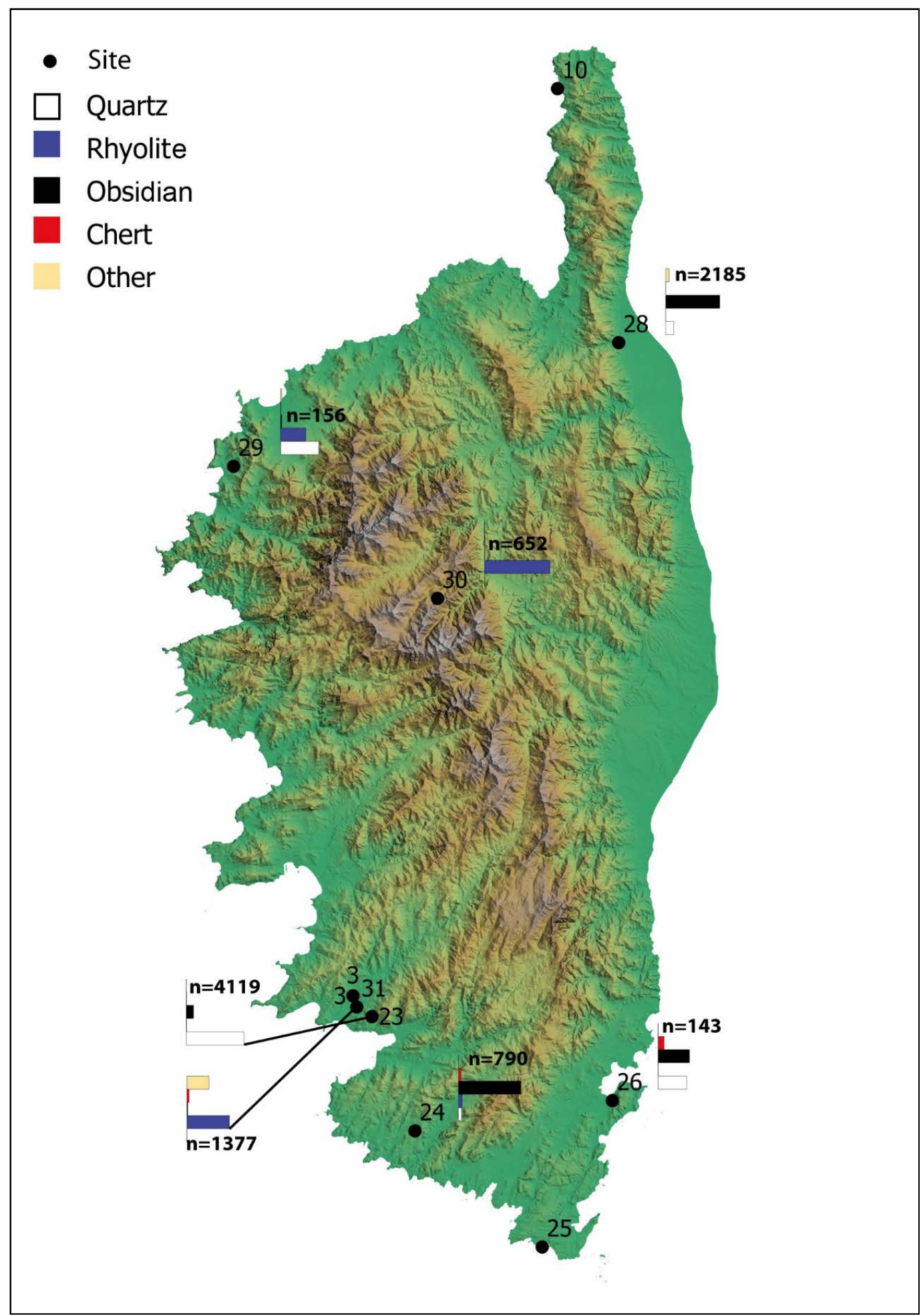

Figure 7. Location of Recent and Final Neolithic sites and representation of raw material distribution when data available. Site number corresponds to first column in Table 1, and, in addition: Recent Neolithic, 28: Monte Grosso; Final Neolithic, 29: Luzzipeu, 30: Plateau d'Alzu, 31: I Calanchi; n: total number of lithic artefacts represented in the diagram. Credits: Maxime Seguin, DRAC Corse. 
Beside this general trend, at the site of Monte Revincu in a funerary context, we observed the introduction of specialized production: a Perfugas (evaporitic facies, SP2a) long blade fragmented by recent heat alteration.

An outstanding result for the period is the identification of six chert artefacts from the Cap Corse (Scaffa Piana and A Guaïta) provenanced to the Marche-Umbria area of the Italian Peninsula. Both Scaglia Rossa (characterized by pelagic foraminifera) and Maiollica (characterized by Radiolaria) cherts are represented. In Scaffa Piana, this material is introduced as two arrow heads. Several unidentified facies have also been observed in Cap Corse sites.

The percentage of cortical artefacts is slightly above $10 \%$ in Vasculacciu but lower than $5 \%$ in all the other sites. This may indicate mainly an introduction of blanks and end products to the sites. Based in particular on the study of Vasculacciu and on our observations, chert knapping is directed to the production of flakes during the Middle Neolithic, with nucleus scarce in the assemblages.

\subsection{Recent Neolithic}

For the Recent Neolithic, the number of studied sites is limited to six (Table 1) and they are mainly located in Southern Corsica (Figure 5). The proportion of chert in the assemblages remains low but we observe a significant increase in both proportions and quantities of obsidian. These results attests to the diffusion networks operating from the Monte Arci workshops in Sardinia (Lugliè 2012). This may have had repercussions for Perfugas chert exploitation as might indicate the development of specialized production (chert long blades) in Perfugas Basin (Costa \& Pelegrin 2004; Falchi et al. 2012).

During the Recent Neolithic, we observe a revival of Perfugas chert diffusion in Corsica, mainly bedded cherts (SP1) and rhomboedric features (SP5) cherts, besides other facies which were not exploited during the Ancient Neolithic, like clastic cherts (SP6) and grey silcrete (SP8). It is interesting to note, for the understanding of Perfugas area occupation, that those materials occur in distinct areas of the basin. The calcedonious facies (Figure 7) are still well represented but appear less important than in the Middle Neolithic.

Among the corpus of sites, Montlaur is outstanding (Ranche in prep.). Located at the extreme south of the island, close to the sea and to Sardinia, it might have a specific status. Its chert assemblage seems important but obsidian is at least 10 times more abundant. It shows strong connections with Sardinian cultures based on lithic typology and ceramics (Ferreira et al. 2014). Flake industry dominates but blades are frequent in Montlaur. One fifth of imported cherts are end-products. The site received Perfugas chert bifacial arrow heads which have also been observed in the Recent Neolithic layers of Basi. A specific production may have occurred in Sardinia for that kind of product but no related workshops are known currently.

\subsection{Final Neolithic}

During the Final Neolithic, locally called the "Terrinian” culture, chert disappears from Northern Corsica sites, although there is still a discrete presence in the south. Obsidian importations are also in decline. Figure 5 shows that local raw material dominates the lithic industry, with rhyolite increasing both in Southern and Northern Corsica. Thus, the use of chert is still attested but diffusion networks collapse.

Even if the number of studied sites is limited for this period, we can make qualitative assumptions. In Basi, among the 37 artefacts analysed, nearly half could not be categorised as they were thermally altered. The unaltered artefacts are distributed between Perfugas facies (12), unknown origins (6) and calcedonious facies (SC: 3). In I Calanchi, chert is still represented by less than 50 of artefacts, including some arrow heads, as well as rhyolite ones

Journal of Lithic Studies (2020) vol. 7, nr. 2, p. 1-24 doi:https://doi.org/10.2218/jls.5406 
which are predominant. For this period, it is highly probable that some chert material, as well as obsidian, has been collected and reshaped from artefacts from older sites. A possible evolution of procurement during the Final Neolithic (one millennium long) has been proposed by M. Rémicourt et al. (2016) but this remains to be studied. To do so, our site corpus for this period will have to be extended.

\section{Discussion and conclusions}

The proposed study provides a renewal of the knowledge on Corsican chert procurement through the systematic survey of a major Sardinian chert source and an extensive study of the main Neolithic sites of the island. The main limitation is the heterogeneity of data and reliability of some chrono-cultural attributions. However, the excavations in progress or expected will balance this point in future years. It also demonstrates that Sardinian secondary sources should not be neglected and may draw our attention in upcoming surveys.

The results show the connections between Sardinia and Corsica throughout the Neolithic. Those connections seem to contain a certain rhythm with periods of expansion (Ancient Neolithic, Recent Neolithic) and periods of decline (Middle Neolithic, Final Neolithic). At some periods, it occurs because of the concurrence of another lithic network (Recent Neolithic), and at others it may fingerprint a decrease in contacts and group circulation (Final Neolithic).

Lithic raw material sources had a specific status among landscape and territories as they provided essential resources. However, their extensive use or discard may have been linked to social and political factors. The use of one specific material, like obsidian or Perfugas chert, might reveal the weight and prevalence of some cultural groups at one particular period. This particular point may explain, partly at least, the evolution highlighted during the Neolithic. In this respect, the procurement breaks highlighted between the Ancient Neolithic and the Middle Neolithic with the abandonment of Perfugas chert to the benefit of calcedonious ones from secondary sources is significant. It does not only correspond to a change of material but above all to a change of behaviours (or people?).

The study shows also that in terms of procurement patterns, the island is separated into two parts: Northern and Southern Corsica, separated by Central mountain massifs. Southern Corsica appears more open to Sardinian lithic diffusion networks throughout the Neolithic period. Northern Corsica appears, except perhaps during the Recent Neolithic, to be at the receiving end of Sardinian chert and obsidian diffusion, with the introduction of tools and some blanks. Northern Corsica is also connected to Eastern networks, with the arrival of Continental Italy materials during the Middle Neolithic.

Such regional studies of chert procurement at the scale of the Mediterranean are scarce. It is thus complicated to compare our results with contemporary processes occurring on other Mediterranean islands or even on the continent. However, the potential of provenance studies is fully revealed when conducted over large areas and on a long time scale.

A recent work conducted on the techno-economy of chert in Sardinia (Melosu 2013) allows us however to foresee chert procurement patterns at a general level. During the Sardinian Ancient Neolithic, procurement depends on source proximity. Indeed, in areas where chert is available, it composes the main part of assemblages. Its acquisition was direct and mostly focused on colluvial and alluvial deposits. In Southern Sardinia, where obsidian outcrops, this material was preferentially exploited. No specific procurement organization exists and opportunistic behaviour seems to prevail. It is important to stress that in this context, the importation of Perfugas chert in important quantities in Southern Corsica (Renaghju, Basi) might indicate privileged contacts with Northern Sardinian groups settled

Journal of Lithic Studies (2020) vol. 7, nr. 2, p. 1-24 doi:https://doi.org/10.2218/jls.5406 
close to Perfugas sources. In the same perspective, the case of A Petra could be interpreted as maritime connections with people from the Monte Arci area.

During the Middle Neolithic ( $5^{\text {th }}$ millennium), obsidian became the dominant raw material across the island of Sardinia independently of the distance, with the development of the Monte Arci workshops (Lugliè 2012). However, we see that in Corsica, at the same time, in terms of quantities, the diffusion of the volcanic glass remains low in a majority of sites (except Vasculacciu). It might indicate a delay for the implementation of diffusion networks between the two islands.

During the Sardinian Recent Neolithic (Ozieri culture, $4^{\text {th }}$ millennium), the flint from the Perfugas sources started to circulate in the island (Melosu \& Lugliè 2017). This material spread in the form of artefacts produced with high technical investment and skill: long blades obtained especially by (simple or by lever) pressure technique made out of very high quality flint (Costa \& Pelegrin 2004). Parallel to this specialized production, an expedient lithic industry, exploiting almost exclusively low-quality flint, has been identified.

However, exploitation of chert materials is still occasional, for obsidian predominates in the lithic assemblages until the end of this phase too. This pattern is quite concordant with what can be observed in Corsica although very few (three specimens) Perfugas chert long blades (or dagger) are known on the island from contexts poorly documented. Indeed, specialized productions introduced in Corsica rather correspond to chert arrow heads (Basi, Montlaur).

Throughout the Neolithic, chert techno-economic patterns of Sardinia appear to be very similar to that observed in Corsica, with a production principally turned toward flakes from the Middle Neolithic.

Chert provenance data can be supported and completed by the result of several studies of raw materials which were very well developed for 20 years in Corsica: rhyolite (AmezianeFederzoni et al. 2014), obsidian, polished stones (Colonna et al. 2014) and clays (PaoliniSaez 2014). Interactions between Corsica and Continental Italy during the Middle Neolithic is ascertained by jadeite and omphacitite axes coming from the Italian Alps (Errera in BressyLeandri et al. 2014). Moreover, a few obsidian analyses of artefacts from Corsican sites dated to the Ancient and Recent Neolithic have identified origins from the Palmarola and Lipari islands along the Italian Western coast. However, the chronological contexts are not fully reliable (Le Bourdonnec et al. 2010). Within Corsica, North-South circulations are attested by rhyolite diffusion (Leck et al. 2018) and clay materials (Paolini-Saez 2014). Summarizing those data improves our perception of the place of Corsica within Western Mediterranean lithic networks.

Considering the state of the art, the heterogeneity of data and the lack of systematic techno-economic approaches on lithic industries, we currently cannot infer as far as we would like to on transport patterns. A territorial approach considering the nature and status of each site would help to further the subject. However, we can assume on the base of the diversity of procurement profiles per period, that chert diffusion towards Corsica includes a wide range of scenarios, from direct regular procurement, to occasional forays, from the possible existence of peddlers (Costa 2006), to the movement of individuals or groups. Whatever the case, it induces different scenarios, depending on the considered period, which includes both terrestrial and maritime territories. Reconstructing spatial organization is challenging because it corresponds to the projection of the social systems (Brunet et al. 1993: 115-132) of prehistoric people. This perspective should head our further works. 


\section{Acknowledgements}

The present study was mainly funded by the French Ministry of Culture. We acknowledge the heads of excavation who allowed the study of the lithic remains they recorded: André D’Anna, François de Lanfranchi, Franck Leandri, Françoise Lorenzi, Jacques Magdeleine, Sylvain Mazet, Paul Nebbia, Pierre Neuville, Jean-Claude Ottaviani, Alain Pasquet, Kewin Peche-Quilichini, Thomas Perrin, Christophe Ranché, Pascal Tramoni, Michel-Claude Weiss. We are grateful to the heads of Museums who made the collections available for the study: Vaidehi Glibert, Janine de Lanfranchi and Laurence Pinet.

We thank especially Antonin Tomasso and Stefano Bertola for their help with the identification of Italian Peninsula cherts.

We are grateful to the reviewers who contributed to the upgrade of the paper.

We express finally our gratitude to Maxime Seguin for his contribution to the paper.

\section{References}

Ameziane-Federzoni, N. 2011, Approvisionnement et diffusion de la rhyolite dans le Nord de la Corse au Néolithique ancien et moyen. PhD thesis at the Corsica University, Corte, $284 \mathrm{p}$.

Ameziane-Federzoni, N., Ottaviani-Spella, M.M., Berlinghi, A. \& Quilichini, Y. 2014, L'exploitation d'un gîte primaire de rhyolite au cours de la préhistoire récente dans le centre de la Corse: l'exemple du plateau d'Alzu. In: Chronologie de la Préhistoire récente dans le Sud de la France. Actes des 10e Rencontres méridionales de Préhistoire Récente, 18-20 October 2012, Porticcio (Sénépart, I., Leandri, F., Cauliez, J., Perrin \& T., Thirault, É. Eds.), Archives d’Ecologie Préhistorique, Toulouse: p. 411-421.

Bressy, C. 2003, Caractérisation et gestion du silex des sites mésolithiques et néolithiques du Nord-Ouest de l'arc alpin. Une approche pétrographique et géochimique. British Archaeological Reports International Series 1114, 295 p.

Bressy-Leandri, C. 2014, Matières premières lithiques en Corse: territoires et interactions culturelles au Néolithique. Rapport de Programme collectif de recherche, SRA Corse, Ajaccio, $110 \mathrm{p}$.

Bressy-Leandri, C. 2016, Caractérisation et provenance des silex de sites néolithiques corses. In: Ressources lithiques, productions et transferts entre Alpes et Méditerranée. Actes de la journée de la Société Préhistorique Française, 28-29 March 2013, Nice (Tomasso, A., Binder, D., Martino, G., Porraz, G., Simon, P. \& Naudinot, N. Eds.), Société préhistorique française, Paris: p. 277-288.

Bressy, C., Bellot-Gurlet, L., Convertini, F., D’Anna, A., Guendon, J.-L., Pelletier, D. \& Tramoni, P. 2007, Matières premières et circulation des matériaux dans le Néolithique ancien de Renaghju (Sartène, Corse-du-Sud). In: Corse et Sardaigne préhistoriques, relations et échanges dans le contexte méditerranéen, Actes du 128e Congrès National des Sociétés Historiques et Scientifiques, 2003, Bastia (D’Anna, A., Cesari, J., Ogel, L., \& Vaquer, J. Eds.), Documents préhistoriques, 22: p. 87-98.

Bressy, C., D’Anna, A., Poupeau, G., Le Bourdonnec, F.-X., Bellot-Gurlet, L., Leandri, F., Tramoni, P. \& Demouche, F. 2008, Chert and obsidian procurement of three Corsican sites during the 6th and 5th millenniums BC. Comptes Rendus Palevol, 7(4): 237-248. doi:10.1016/j.crpv.2008.02.007 
Bressy-Leandri, C., Leandri, F., Bellot-Gurlet, L., Demouche, F., Errera, M., AmezianeFederzoni, N., Gilabert, C., Le Bourdonnec, F.-X., Luglié, C. \& Poupeau, G. 2014, Le Monte Revincu (Santo-Pietro-di-Tenda, Haute-Corse): une communauté villageoise de la fin du Ve millénaire av. J.-C. au cœur des échanges lithiques en Méditerranée Occidentale. In: La Corse et le Monde Méditerranéen des origines au Moyen Âge: échanges et circuits commerciaux. Actes du Colloques de Bastia, 21 November 2013, Bastia, Bulletin de la Société des Sciences historiques et naturelles de Corse, $\mathrm{n}^{\circ} 746-$ 747: p. 21- 40.

Bressy-Leandri, C., Fernandes, P. \& Seguin, M. 2019, Provenance des silex des sites préhistoriques corses. Rapport de prospection thématique, SRA Corse, Ajaccio, 189 p.

Brunet, R., Ferras, R. \& Théry, H. 1993, Les mots de la géographie. Reclus, La Documentation Française, 518 p.

Cesari, J., Courtaud, P., Leandri, F., Perrin, T. \& Manen, C. 2014, Le site de Campu Stefanu (Sollacaro, Corse-du-Sud). Une occupation du Mésolithique et du Néolithique ancien dans le contexte corso-sarde. In: La transition néolithique en Méditerranée. Actes du colloque Transitions en Méditerranée, ou comment des chasseurs devinrent agriculteurs, 14-15 April 2011, Toulouse (Manen, C., Perrin, T. \& Guilaine, J. Eds.), Éditions Errance, Archives d’Écologie Préhistorique, Arles-Toulouse: p. 283-306.

Colonna, A., Dubar, M. \& Monge, G. 2014, Étude des haches polies corses: premiers résultats des analyses non destructives de dix haches par diffractométrie $\mathrm{X}$ en faisceaux parallèles. In: Chronologie de la Préhistoire récente dans le Sud de la France. Actes des 10e Rencontres méridionales de Préhistoire Récente, 18-20 October 2012, Porticcio (Sénépart, I., Leandri, F., Cauliez, J., Perrin \& T., Thirault, É. Eds.), Archives d’Ecologie Préhistorique, Toulouse: p. 423-430.

Costa, L.J. 2006, Récents acquis sur la circulation préhistorique de l'obsidienne en Corse. Bulletin de la Société Préhistorique Française, 103(1): 71-86. doi:10.3406/bspf.2006.13396

Costa, L. J. \& Pelegrin, J. 2004, Une production de grandes lames par pression à la fin du Néolithique, dans le nord de la Sardaigne (Contraguda, Perfugas). Bulletin de la Société Préhistorique Française, 101(4): 867-873. doi:10.3406/bspf.2004.13072

Falchi, P., Fenu, P., Martini, F., Pitzalis, G., Sarti L. \& Tozzi, C. 2012, L’insediamento neolitico di Contraguda (Perfugas, Sassari): aggiornamento delle ricerche. In: $L a$ Preistoria e la Protostoria della Sardegna, Firenze. Atti della XLIV Riunione dell'Istituto Italiano di Preistoria e Protostoria, 23-28 November 2009, Sassari, vol. II: p. 503-508. http://digital.casalini.it/2629607

Ferreira, P., Commandré, I. \& Tramoni, P. 2014, Ancienne caserne de Montlaur: Corse-duSud (2A), Bonifacio. Rapport de diagnostic, Inrap, 188 p.

Fernandes, P. 2012, Itinéraires et transformations du silex: une pétroarchéologie refondée, application au Paléolithique moyen. PhD thesis at the Bordeaux I University, Bordeaux, $623 \mathrm{p}$.

Fernandes, P., Le Bourdonnec, F.X., Raynal, J.-P., Poupeau, G., Piboule, M. \& Moncel, M.H. 2007, Origins of prehistoric flints: The neocortex memory revealed by scanning electron microscopy. Comptes rendus Palevol, 6(8): 557-568. doi:10.1016/j.crpv.2007.09.015 
de Lanfranchi, F. 1980, L’obsidienne préhistorique corso-sarde: les échanges et les axes de circulation. Bulletin de la Société Préhistorique Française, 77(4): 115-122. doi:10.3406/bspf.1980.5255

Le Bourdonnec, F.-X., Delerue, S., Dubernet, S., Moretto, P., Calligaro, T., Dran, J.-C. \& Poupeau, G. 2005, PIXE characterization of Western Mediterranean and Anatolian obsidians and Neolithic provenance studies. Nuclear Instruments and Methods Physics Research, 240(1-2): 595-599. doi:10.1016/J.NIMB.2005.06.156

Le Bourdonnec, F.-X., Bontempi, J.-M., Marini, N., Mazet, S., Neuville, P.-F., Poupeau, G. \& Sicurani, J. 2010, SEM-EDS characterization of western Mediterranean obsidians and the Neolithic site of A Fuata (Corsica). Journal of Archaeological Science, 37(1): 92106. doi:10.1016/j.jas.2009.09.016

Leck, A., Le Bourdonnec, F.-X., Gratuze, B., Dubernet, S., Ameziane-Federzoni, N., BressyLeandri, C., Chapoulie, R., Mazet, S., Bontempi, J.-M., Marini, N., Remicourt, M. \& Perrin, T. 2018, Provenance d'artefacts en rhyolite corse: évaluation des méthodes d'analyse géochimique. Comptes Rendus Palevol, 17(3): 220-232. doi:10.1016/j.crpv.2017.10.003

Lugliè, C. 2012, From the Perspective of the Source. Neolithic production and exchange of Monte Arci obsidians (Central-western Sardinia). In: Raw materials, products and ideas circulation in the Western Mediterranean Basin (VII-III aC). Proceedings of the International Conference in the Neolithic. Museum of Gavà, Rubricatum 5: p. 173-180.

Martinet, L. 2017, Les interactions culturelles corso-sardes à la lumière des industries lithiques: matières premières, productions et usages à l'abri des Castelli (Haute Corse). Master tesis at the Nice Sophia Antipolis University, Nice, 156 p.

Martinet, L. 2019, Etude techno-économique de quelques industries en pierres taillées corses du VIe et de la première moitié du Ve millénaire av. n. è. Report, SRA Corse, Ajaccio, $157 \mathrm{p}$.

Melosu, B. 2013, Les industries lithiques en silex de Sardaigne au Néolithique: approvisionnements, circulations et productions. Premières approches. $\mathrm{PhD}$ thesis at the Aix-Marseille University, Aix-en-Provence, vol. 1: 400 p., vol. 2: 116 p.

Melosu, B. \& Lugliè, C. 2017, What are these blades for? Flint blade production and circulation in the Final Neolithic. In: The exploitation of raw materials in Prehistory: sourcing, processing and distribution (Pereira, T., Bicho, N. \& Terradas, X. Eds.), Cambridge Scholars Publishing: p. 222-233.

Paolini-Saez, H. 2014, Apport des études typo-technologiques pour la compréhension des productions céramiques corses des $\mathrm{VI}^{\mathrm{e}}$ et $\mathrm{V}^{\mathrm{e}}$ millénaires. In: Chronologie de la Préhistoire récente dans le Sud de la France. Actes des 10e Rencontres méridionales de Préhistoire Récente, 18-20 October 2012, Porticcio (Sénépart, I., Leandri, F., Cauliez, J., Perrin \& T., Thirault, É. Eds.), Archives d'Ecologie Préhistorique, Toulouse: p. 373384.

Pasquet, A. \& Demouche, F. 2008, Punta di Caniscione, Monaccia-d'Aullène, Corse-du-Sud. Rapport de fouille, Ajaccio, SRA Corse, 73 p.

Perrin, T. 2015, Abri Southwell 2015. Rapport de sondage archéologique, SRA Corse, Ajaccio, 93 p.

Perrin, T. 2016, Basi, Serra-di-Ferro. Rapport de fouille, SRA Corse, Ajaccio, 188 p. 
Ranché, C. in preparation, Ancienne caserne de Montlaur: Corse-du-Sud (2A), Bonifacio.

Rapport de fouille préventive, Inrap.

Rémicourt, M., Cesari, J. \& Tramoni, P. 2016, L’industrie lithique taillée de la couche B du gisement d'I Calanchi à Sollacaro (Corse-du-Sud): un reflet des traditions et des mutations du terrinien dans le sud de la Corse. In: De la tombe au territoire \& Actualité de la recherche. Actes des 11e Rencontres Méridionales de Préhistoire Récente, 25-27 September 2014, Montpellier (Cauliez, J., Sénépart, I., Jallot, L., de Labriffe, P., Gilabert, C. \& Gutherz, X. Eds.), Archives d’Ecologie Préhistorique, Toulouse: p. 329344.

Sicurani, J. 2008, Etude technologique et typologique du matériel lithique taillé néolithique trouvé en place dans quelques sites majeurs du nord-ouest (Balagne) de la Corse. PhD thesis at the Corsica University, Corte, 714 p.

Tykot, R.H. 1996, Obsidian procurement and distribution in the Central and Western Mediterranean. Journal of Mediterranean Archaeology, 9(1): 39-82.

Journal of Lithic Studies (2020) vol. 7, nr. 2, p. 1-24 doi:https://doi.org/10.2218/jls.5406 